\title{
TINGKAT KONSEKUENSI BAHAYA PADA AKTIVITAS PENGAWASAN KEDATANGAN DAN KEBERANGKATAN KAPAL PERIKANAN DI POS PELAYANAN JAKARTA
}

\author{
Hazard Consequences Level of Surveillance Activities in Arrival and Departure of Fishing Vessels in \\ Jakarta Service Based \\ Oleh : \\ Ismajaya ${ }^{1^{*}}$, Fis Purwangka ${ }^{2}$, Budhi Hascaryo Iskandar ${ }^{2}$ \\ ${ }^{1}$ Pengawas Sumber Daya Kelautan dan Perikanan \\ 2 Departemen PSP FPIK IPB Bogor \\ *Korespondensi: ismajaya@gmail.com
}

\begin{abstract}
ABSTRAK
Kegiatan pengawasan penangkapan ikan di Pelabuhan dianggap kegiatan rutin tanpa memperhitungkan konsekuensi bahaya akibat kerja bagi pengawas perikanan. Penelitian ini bertujuan untuk mengidentifikasi dan menilai besarnya konsekuensi bahaya kegiatan pengawasan kedatangan dan keberangkatan kapal perikanan. Metode Hazard Analysis and Risk Assessment (HIRA) digunakan dalam analisis data penelitian ini. Hasil penelitian menunjukkan bahwa kegiatan pengawasan kedatangan dan keberangkatan kapal terdiri dari enam kegiatan utama. Hasil analisis dengan metode HIRA menunjukkan bahwa keenam kegiatan utama berdampak pada delapan jenis konsekuensi yaitu fatalities, injuries, evaquation, property damage, critical infrastructure, enviromental damage, bussiness financial impact dan psicosocial impact. Nilai terbesar konsekuensi dari kegiatan pengawasan kedatangan dan keberangkatan kapal perikanan berada pada kegiatan pra-pengawasan dan pascapengawasan dalam aktivitas perjalanan dari dan menuju pos pelayanan. Nilai total konsekuensi adalah 12 termasuk kedalam kriteria konsekuensi 5 yaitu very severe (sangat parah). Kegiatan pengawasan kedatangan dan keberangkatan kapal penangkap dan kapal pengangkut ikan masing-masing memberikan nilai total konsekuensi terbesar adalah 10 termasuk kriteria konsekuensi 4 severe (parah) dalam aktivitas perjalanan dari dan menuju objek pengawasan, pemeriksaan VMS dan pemeriksaan CCTV. Kegiatan pengawasan kedatangan dan keberangkatan kapal secara keseluruhan memberikan konsekuensi bahaya terbesar terhadap injuries dan property damage.
\end{abstract}

Kata kunci : Pengawas Perikanan, Kedatangan kapal, Keberangkatan kapal, HIRA.

\begin{abstract}
Activities of fishing vessel surveillances by fisheries inspector has been considered as a routine task without any considering of hazard consequences that might be faced by the fisheries inspectors. The objective of this study was to identify and assess the hazard consequences of the arrival and departure of fishing vessels in Jakarta service based. The Hazard Analysis and Risk Assessment (HIRA) method was used in this study. The results showed that in the arrival and departure of fishing vessel consist of six main activities. These six main activities having impact to eight types of consequences, that were fatalities, injuries, evacuation, property damage, critical infrastructure, environmental damage, financial impact business and psicosocial impact. The highest consequence values of the arrival and departure of fishing vessels was in pre-supervision and post-supervision, which activities were from and going to the service based. The total value of consequences was 12 categorized in criterion 5 (very severe). The arrival and departure surveillance on the fishing and fish carrier vessels had the highest consequence value which was 10 categorized on criterion 4 (severe), which activities were from
\end{abstract}


and going to the supervision object, VMS and CCTV inspection. In all surveillance activities of arrival and departure of fishing vessels, the highest hazard consequences was through injuries and property damages.

Keywords : Fisheries Inspector, Ship arrival, Ship departure, and HIRA.

\section{PENDAHULUAN}

Pengawas perikanan merupakan petugas negara yang diberi wewenang dalam melakukan pengawasan bidang perikanan dan kelautan sesuai dengan amanat Undang-Undang Republik Indonesia Nomor 45 Tahun 2009 tentang perubahan atas Undang-Undang Republik Indonesia Nomor 31 Tahun 2004 tentang perikanan pasal 66. Kegiatan perikanan tangkap merupakan salah satu objek pengawasan bidang perikanan yang dilakukan oleh pengawas perikanan.

Pengawasan perikanan tangkap dilakukan di pelabuhan-pelabuhan perikanan dan di laut (Aji et al. 2017). Pengawasan di pelabuhan merupakan awal dan akhir suksesnya pengawasan kegiatan perikanan tangkap yang terbebas dari kegiatan IUU Fishing. Alat kontrol kegiatan perikanan tangkap berupa Hasil Pengawasan Kapal Perikanan (HPK) dan Surat Laik Operasi Kapal Perikanan (SLO) sesuai amanat Peraturan Menteri Kelautan dan Perikanan Nomor 1 Tahun 2017. HPK dibagi menjadi empat yaitu pada HPK kedatangan kapal penangkap ikan, HPK kedatangan kapal pengangkut ikan, HPK keberangkatan kapal penangkap ikan dan HPK keberangkatan kapal pengangkut ikan. HPK keberangkatan kapal baik untuk kapal penangkap maupun kapal pengangkut ikan merupakan syarat terbitnya SLO.

Aktivitas yang dilakukan pengawas perikanan dalam pengawasan kegiatan perikanan tangkap terindikasi mempunyai konsekuensi bahaya. Kegiatan yang dianggap biasa dan dilakukan setiap hari cenderung diabaikan konsekuensi bahayanya, disisi lain keberhasilan pengawas perikanan dalam melaksanakan kegiatan pengawasan kapal pada saat kedatangan dan keberangkatan merupakan salah satu upaya yang berperan penting dalam mencegah kegiatan IUU Fishing.

Berdasarkan permasalahan tersebut maka perlu untuk mengetahui konsekuensi bahaya kegiatan pengawasan kapal pada saat kedatangan dan keberangkatan sebagai dasar antisipasi dalam mengendalikan konsekuensi bahaya yang mungkin terjadi pada pengawas perikanan. Konsekuensi bahaya merupakan akibat dari suatu kejadian yang berbahaya (ILO 2013).

Tujuan penelitian ini adalah untuk mengidentifikasi dan menilai besarnya konsekuensi bahaya pada kegiatan pengawasan kegiatan kedatangan dan keberangkatan kapal perikanan.

\section{METODE PENELITIAN}

Penelitian dilakukan di pangkalan PSDKP Jakarta melalui dua pos pelayanan yaitu Pos pelayanan PPS Nizam Zachman dan Pos pelayanan PPN Muara Angke pada bulan Desember 2018 sampai dengan Januari 2019. Pengumpulan data dilakukan dengan cara observasi langsung kegiatan pengawasan kedatangan keberangkatan kapal perikanan dan wawancara terhadap 22 Pengawas Perikanan yang bertugas di pangkalan PSDKP Jakarta. Berdasarkan sifat masalah dan analisa datanya, penelitian ini termasuk dalam penelitian deskriptif sebab penelitian ini tidak melakukan perbandingan atau penghubungan antar variabel.

Populasi dalam penelitian ini adalah pengawas perikanan yang bertugas di Pangkalan PSDKP Jakarta yang melakukan kegiatan pengawasan terhadap kedatangan dan keberangkatan kapal perikanan di pos pelayanan Pelabuhan Perikanan Muara Baru dan pos pelayanan Pelabuhan Muara Angke. 
Variabel yang diteliti dalam penelitian ini adalah identifikasi bahaya, penilaian risiko dan penilaian tingkat risiko pada kegiatan pengawasan kedatangan dan keberangkatan kapal perikanan.

Observasi dan wawancara digunakan untuk mengetahui proses kerja pengawasan kedatangan dan keberangkatan kapal perikanan, potensi bahaya yang ada, besarnya risiko pekerjaan dan kondisi lingkungan kerjanya. Data lain yang dikumpulkan adalah gambaran umum pangkalan PSDKP Jakarta, prosedur kerja, jumlah pekerja dan data terkait lainnya dengan penelitian ini.

Teknik pengolahan dan analisis data yang dilakukan mengacu pada metode HIRA yang terdapat pada EMO (2012). Metode ini juga digunakan oleh Purwangka (2013), Handayani et al. (2014) dan Minggo YD et al. (2017). Dalam penelitian ini dibahas sampai dengan tahap risk assessment untuk menentukan besarnya konsekuensi bahaya yang dapat diketahui pada kegiatan pengawasan kedatangan dan keberangkatan kapal perikanan yang berjumlah delapan jenis konsekuensi yaitu: fatalities, injuries, evaquation, property damage, critical infrastructure impact, enviromental damage, bussiness financial impact dan psicosocial impact dengan kriteria tercantum dalam tabel-tabel berikut:

Tabel 1 Skala fatalities dalam HIRA

\begin{tabular}{cll}
\hline Consequence & Category & \multicolumn{1}{c}{ Description } \\
\hline $\mathbf{0}$ & None & Tidak mungkin menghasilkan korban jiwa \\
$\mathbf{1}$ & Minor & Dapat mengakibatkan kurang dari lima korban jiwa \\
$\mathbf{2}$ & Moderate & Dapat mengakibatkan 5 - 10 korban jiwa \\
$\mathbf{3}$ & Severe & Dapat mengakibatkan 10 - 50 korban jiwa \\
$\mathbf{4}$ & Catastropic & Dapat menyebabkan korban jiwa $>50$ \\
\hline
\end{tabular}

Sumber : diadaptasi dari Emergency Management Ontario 2012

Tabel 2 Skala Injuries dalam HIRA

\begin{tabular}{cll}
\hline Consequence & Category & \multicolumn{1}{c}{ Description } \\
\hline $\mathbf{0}$ & None & Tidak mungkin menyebabkan cedera \\
$\mathbf{1}$ & Minor & Luka ringan, membutuhkan penanganan langsung \\
$\mathbf{2}$ & Moderate & Cedera ringan, membutuhkan penanganan medis dokter/ \\
& & rumah sakit, membutuhkan waktu penyembuhan \\
$\mathbf{3}$ & Severe & Cedera berat/serius, mengakibatkan cacat, membutuhkan \\
& & waktu penyembuhan hingga tidak masuk kerja
\end{tabular}

Sumber : diadaptasi dari Emergency Management Ontario 2012

Tabel 3 Skala evaquation dalam HIRA

\begin{tabular}{|c|c|c|}
\hline Consequence & Category & Description \\
\hline 0 & None & $\begin{array}{l}\text { Tidak mungkin menghasilkan tempat penampungan } \\
\text { evakuasi di tempat pesanan, atau orang-orang terdampar }\end{array}$ \\
\hline 1 & Minor & $\begin{array}{l}\text { Bisa mengakibatkan kurang dari } 100 \text { orang dievakuasi, } \\
\text { terlindung di tempat atau terdampar }\end{array}$ \\
\hline 2 & Moderate & $\begin{array}{l}\text { Bisa mengakibatkan } 100 \text { - } 500 \text { orang dievakuasi, terlindung } \\
\text { di tempat atau terdampar }\end{array}$ \\
\hline 3 & Severe & $\begin{array}{l}\text { Bisa mengakibatkan lebih dari } 500 \text { orang dievakuasi, } \\
\text { terlindung di tempat atau terdampar }\end{array}$ \\
\hline
\end{tabular}


Tabel 4 Skala property damage dalam HIRA

\begin{tabular}{cll}
\hline Consequence & Category & \multicolumn{1}{c}{ Description } \\
\hline $\mathbf{0}$ & None & Tidak mungkin menghasilkan kerusakan property \\
$\mathbf{1}$ & Minor & Dapat menyebabkan kerusakan kecil property \\
$\mathbf{2}$ & Moderate & Kerusakan parah \\
$\mathbf{3}$ & Severe & Kerusakan parah dan tidak bisa digunakan lagi \\
\hline
\end{tabular}

Sumber : diadaptasi dari Emergency Management Ontario 2012

Tabel 5 Skala critical infrastructure service impact dalam HIRA

\begin{tabular}{cll}
\hline Consequence & Category & \multicolumn{1}{c}{ Description } \\
\hline $\mathbf{0}$ & None & Tidak mungkin mengganggu layanan infrastruktur penting \\
$\mathbf{1}$ & Minor & Dapat mengganggu 1 layanan infrastruktur penting \\
$\mathbf{2}$ & Moderate & Dapat mengganggu 2 - 3 layanan infrastruktur penting \\
$\mathbf{3}$ & Severe & Dapat mengganggu lebih dari 3 layanan infrastruktur penting \\
\hline
\end{tabular}

Sumber : diadaptasi dari Emergency Management Ontario 2012

Tabel 6 Skala enviromental damage dalam HIRA

\begin{tabular}{|c|c|c|}
\hline Consequence & Category & Description \\
\hline 0 & None & Tidak mungkin menghasilkan kerusakan lingkungan \\
\hline 1 & Minor & $\begin{array}{l}\text { Dapat menyebabkan kerusakan lokal dan dapat } \\
\text { dikembalikan. Cepat membersihkan mungkin dapat } \\
\text { dilakukan }\end{array}$ \\
\hline 2 & Moderate & $\begin{array}{l}\text { Dapat menyebabkan kerusakan besar tetapi dapat } \\
\text { dikembalikan. Membersihkan penuh sulit }\end{array}$ \\
\hline 3 & Severe & $\begin{array}{l}\text { Dapat menyebabkan kerusakan lingkungan yang parah dan } \\
\text { tidak dapat dipulihkan. Pembersihan penuh tidak mungkin } \\
\text { dilakukan }\end{array}$ \\
\hline
\end{tabular}

Sumber : diadaptasi dari Emergency Management Ontario 2012

Tabel 7 Skala bussiness financial impact dalam HIRA

\begin{tabular}{cll}
\hline Consequence & Category & \multicolumn{1}{c}{ Description } \\
\hline $\mathbf{0}$ & None & Tidak mungkin mengganggu kegiatan bisnis / keuangan \\
1 & Moderate & Bisa mengakibatkan kerugian bisnis/keuangan \\
$\mathbf{2}$ & Severe & Bisa mengakibatkan kerugian besar bisnis/keuangan \\
\hline
\end{tabular}

Sumber : diadaptasi dari Emergency Management Ontario 2012

Tabel 8 Skala psycosocial impact dalam HIRA

\begin{tabular}{|c|c|c|}
\hline Consequence & Category & Description \\
\hline 0 & None & $\begin{array}{l}\text { Tidak mungkin menghasilkan dampak psikososial yang } \\
\text { signifikan }\end{array}$ \\
\hline 1 & Moderate & $\begin{array}{l}\text { Dampak psikososial yang signifikan termasuk kepanikan } \\
\text { yang terbatas, penimbunan, evakuasi diri dan dampak } \\
\text { psikososial jangka panjang }\end{array}$ \\
\hline 2 & Severe & $\begin{array}{l}\text { Dampak psikososial luas, mis. kepanikan massal, } \\
\text { penimbunan luas dan evakuasi diri dan dampak psikologis } \\
\text { jangka panjang }\end{array}$ \\
\hline
\end{tabular}


Tabel 9 Total consequency dalam HIRA

\begin{tabular}{|c|c|c|c|c|c|c|c|c|c|}
\hline 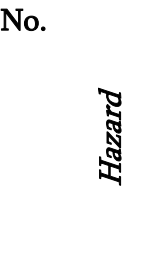 & 营 & : & 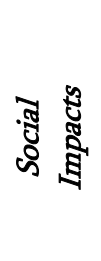 & 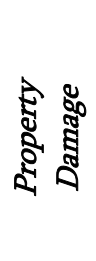 & 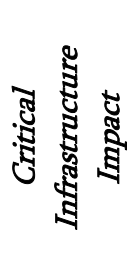 & 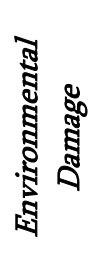 & 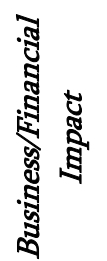 & 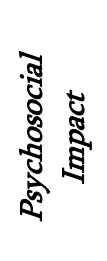 & 종 \\
\hline
\end{tabular}

1.

Sumber : diadaptasi dari Emergency Management Ontario 2012

Tabel 10 Skala total consequency dalam HIRA

\begin{tabular}{ccc}
\hline Total & Consequence & Description \\
\hline $1-4$ & 1 & Minor \\
$5-6$ & 2 & Slight \\
$7-8$ & 3 & Moderate \\
$9-10$ & 4 & Severe \\
$11-12$ & 5 & Very Severe \\
+13 & 6 & Catastropic \\
\hline
\end{tabular}

Sumber : diadaptasi dari Emergency Management Ontario 2012

\section{HASIL DAN PEMBAHASAN}

\section{Pengawas Perikanan Pangkalan Pengawasan Sumber Daya Kelautan dan Perikanan (PSDKP) Jakarta}

Pangkalan PSDKP Jakarta merupakan Unit Pelaksana Teknis (UPT) Direktorat Jenderal Pengawasan Sumber Daya Kelautan dan Perikanan Kementerian Kelautan dan Perikanan. Pangkalan PSDKP Jakarta mempunyai lima satuan pengawasan yang tersebar di Provinsi DKI Jakarta, Provinsi Jawa Barat, Provinsi Banten dan Provinsi Lampung (Permen-KP, 2016). Khusus untuk DKI Jakarta, pusat aktivitas pelayanan kedatangan dan keberangkatan kapal perikanan berada di dua pos pelayanan yang berlokasi di PPS Nizam Zachman dan PPN Muara Angke. Pelayanan terhadap kedatangan dan keberangkatan kapal perikanan di dua lokasi tersebut berlangsung tujuh hari dalam seminggu dengan jam pelayanan dari jam 08.00 WIB s.d 17.00 WIB, permohonan pemeriksaan kapal terakhir jam 15.00 WIB.

Kegiatan pengawasan di Pangkalan PSDKP Jakarta melalui pos pelayanan PPS Nizam Zachman dan PPN Muara Angke merupakan kegiatan rutin pengawas perikanan dalam menjaga dan mengawal tertib pelaksanaan peraturan perundang-undangan dalam bidang perikanan sesuai dengan yang diamanatkan dalam undang-undang nomor 45 tahun 2009 tentang perubahan atas atas undang-undang nomor 31 tahun 2004 tentang perikanan.

Pengawas perikanan yang bertugas di kedua pos pelayanan tersebut berjumlah 19 pengawas perikanan dan 3 orang pimpinan di pangkalan PSDKP Jakarta. Sistem kerja dilakukan dengan metode piket dan membentuk beberapa grup pengawas yang beranggotakan 2-3 orang pengawas perikanan dibantu tenaga harian lepas. Hal ini dilakukan untuk memenuhi pelaksanaan tugas pokok selain kegiatan perikanan tangkap seperti kegiatan pengolahan hasil perikanan, kegiatan budidaya perikanan, kegiatan sumberdaya kelautan dan tugas lainnya yang terkait dengan peraturan perundang-undangan dibidang kelautan dan perikanan.

\section{Kegiatan Pengawasan Kedatangan dan Keberangkatan Kapal Perikanan}

Berdasarkan Peraturan Menteri Kelautan dan Perikanan nomor 17 tahun 2014 tentang pelaksanaan tugas pengawas perikanan pasal 9 huruf (c) menyatakan bahwa salah satu tugas pengawas perikanan melaksanakan pengawasan di Pelabuhan Perikanan dan atau Pelabuhan lain yang ditunjuk. 
Pelabuhan perikanan di Jakarta adalah PPS Nizam Zachman dan PPN Muara Angke, keduanya merupakan lokasi pos pelayanan pengawasan kedatangan dan keberangkatan kapal perikanan di bawah kendali Pangkalan PSDKP Jakarta. Aktivitas kedua pelabuhan tersebut berlangsung setiap hari dalam melayani kegiatan perikanan tangkap baik ketika kedatangan maupun keberangkatan kapal perikanan. Pengawas perikanan berperan dalam kegiatan pengawasan terhadap kapal-kapal tersebut dalam rangka mengawal tertib peraturan perundang-undangan bidang perikanan agar kegiatannya terbebas dari IUU Fishing. Pengawasannya dilakukan pada saat kedatangan kapal di Pelabuhan perikanan dengan melakukan pemeriksaan kesesuaian administrasi dan teknis kapal yang bersangkutan, demikian juga pada saat keberangkatan kapal perikanan, pengawasan dilakukan dalam rangka menentukan apakah kapal tersebut laik operasional penangkapan maupun pengangkutan ikan yang ditunjukkan dengan diterbitkannya Surat Laik Operasi (SLO) kapal perikanan (Permen-KP 2017).

Kegiatan tersebut diidentifikasi aktivitas pengawas perikanan serta potensi bahaya yang mungkin terjadi selanjutnya dilakukan penilaian konsekuensi yang didapatkan. Menurut Sanusi et al. (2017), menyatakan bahwa dalam Sistem Manajemen Keselamatan dan Kesehatan Kerja (SMK3) secara garis besar kejadian kecelakaan kerja disebabkan oleh 2 faktor yaitu : tindakan manusia yang tidak memenuhi keselamatan kerja (unsafe act) dan keadaan-keadaan lingkungan yang tidak aman (unsafe condition). Ramli (2012) menyatakan dalam proses terjadinya kecelakaan terkait empat unsur produksi yaitu people, equipment, material, environtmen (PEME) yang saling berinteraksi dan bersama-sama menghasilkan barang atau jasa. Teknis identifikasi bahaya yang digunakan adalah metode HIRA (Hazard Identification and Risk Assessment). HIRA adalah suatu proses untuk mengetahui adanya suatu bahaya kemudian menghitung besarnya suatu risiko dan menetapkan apakah risiko tersebut dapat diterima atau tidak (Ambarani dan Tualeka 2016).

Dari hasil penelitian didapatkan kegiatan pengawas perikanan pada kedatangan dan keberangkatan kapal perikanan diperoleh aktivitas utama yang dapat dikelompokkan sebagai berikut :

1. Kegiatan pra-pengawasan;

2. Kegiatan pengawasan kedatangan kapal perikanan tangkap;

3. Kegiatan pengawasan kedatangan kapal pengangkut ikan;

4. Kegiatan pengawasan keberangkatan kapal perikanan tangkap;

5. Kegiatan pengawasan keberangkatan kapal pengangkut ikan;

6. Kegiatan pasca-pengawasan

\section{Kegiatan Pra-Pengawasan}

Potensi bahaya (hazard) adalah suatu kondisi/keadaan pada suatu proses, alat, mesin, bahan atau cara kerja yang secara intrinsik/alamiah dapat menjadikan luka, cidera bahkan kematian pada manusia serta menimbulkan kerusakan pada alat dan lingkungan. Bahaya (danger) adalah suatu kondisi hazard yang terekspos atau terpapar pada lingkungan sekitar dan terdapat peluang besar terjadinya kecelakan (Susihono dan Rini 2013). Potensi bahaya atau dapat disebut juga dengan hazard terdapat hampir di setiap lokasi dimana terdapat suatu aktivitas, baik di rumah, di kantor, di jalan, hingga di tempat kerja (Retnowati 2017).

Pada kegiatan ini aktvitas pengawas perikanan lebih ke arah persiapan hal-hal yang terkait dengan pengawasan. Dari hasil observasi diidentifikasi 5 (lima) sub aktivitas yang dilakukan pengawas perikanan, yaitu : (1) Presensi kehadiran datang, (2) Makan pagi, (3) Perjalanan dari kantor Pangkalan PSDKP Jakarta menuju pos pelayanan Muara Baru (4) Perjalanan dari kantor Pangkalan PSDKP Jakarta menuju pos pelayanan Muara Angke (5) Penyiapan properti pengawasan (HPK, SLO, alat ukur, alat dokumentasi). Sub aktvitas yang menyumbang nilai terbesar bagi konsekuensi pada kegiatan prapengawasan yaitu perjalanan dari kantor Pangkalan PSDKP Jakarta menuju lokasi pos pelayanan Muara Angke dengan potensi bahaya yang ditimbulkan yaitu kecelakaan. Nilai konsekuensi total dari delapan konsekuensi pada aktivitas ini sebesar 12. Nilai tersebut menunjukkan kriteria konsekuensi 5 dengan deskripsi very severe (sangat parah). Nilai konsekuensi dari keseluruhan aktivitas pada kegiatan 
pra-pengawasan menyumbangkan nilai terbesar pada jenis konsekuensi injuries dan properti damage dengan jumlah masing-masing 9 dan 10. Empat konsekuensi lain juga ikut terdampak dalam kegiatannya, dan ada dua nilai konsekuensi yang tidak terdampak sama sekali oleh kegiatan prapengawasan yaitu evaquation dan critical infrastructure impact. Gambar 1 menunjukkan nilai persentase konsekuensi bahaya dari kegiatan pra-pengawasan kedatangan dan keberangkatan kapal perikanan.

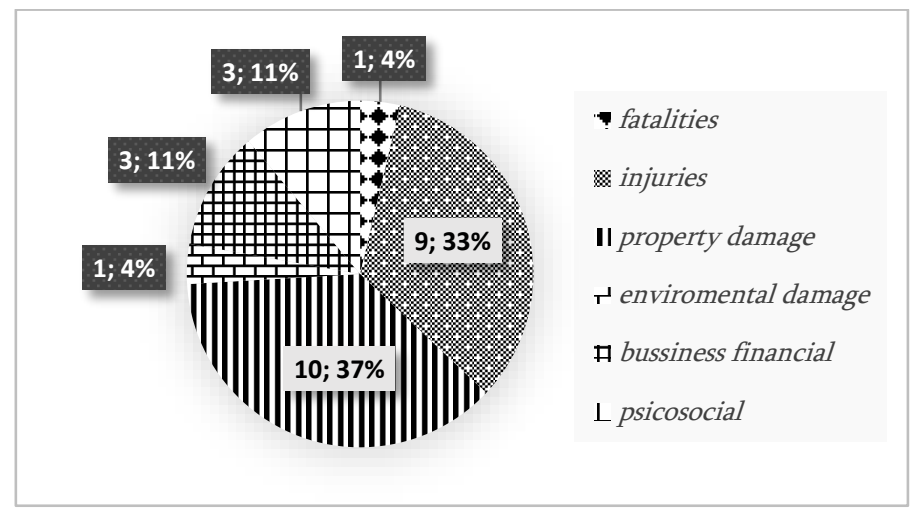

Gambar 1 Konsekuensi bahaya pada kegiatan pra-pengawasan

\section{Kegiatan Pengawasan Kedatangan Kapal Penangkap Ikan}

Pada kegiatan ini terdapat sembilan sub aktivitas, yaitu : (1) Pemeriksaan SLO lama, (2) Pemeriksaan SPB lama, (3) Pemeriksaan SIPI, (4) Pemeriksaan Surat Keterangan Keterangan Aktivasi VMS, (5) Entri data HPK kedatangan, (6) Perjalanan menuju kapal dari pos pelayanan, (7) Pemeriksaan kesesuaian fisik kapal (kesesuaian tanda selar kapal), (8) Pemeriksaan jenis ikan yang ditangkap sesuai alat tangkap, (9) Perjalanan dari kapal menuju pos pelayanan. Sub kegiatan dengan potensi bahaya terbesar terjadi ketika perjalanan dari dan menuju objek pengawasan berupa potensi bahaya terjatuh dari tangga dan celana robek dengan nilai total dari delapan konsekuensi adalah 10, nilai tersebut masuk kedalam konsekuensi kriteria 4 yaitu severe (parah). Konsekuensi yang terdampak pada kegiatan pengawasan kedatangan kapal penangkap ikan ada empat konsekuensi yaitu injuries, properti damage, bussiness financial dan psicosocial dengan jumlah masing-masing konsekuensi adalah 28, 37, 20 dan 8. Konsekuensi bahaya ini terjadi karena ketika aktivitas dari dan menuju objek pengawasan, pengawas perikanan melewati beberapa kapal yang berukuran besar yang harus dilewati melalui tangga antar kapal dengan keadaan tidak standar dan mengharuskan pengawas perikanan naik turun kapal dan melompat antar kapal. Gambar 2 menunjukkan nilai persentase konsekuensi bahaya pada kegiatan pengawasan kedatangan kapal penangkap ikan.

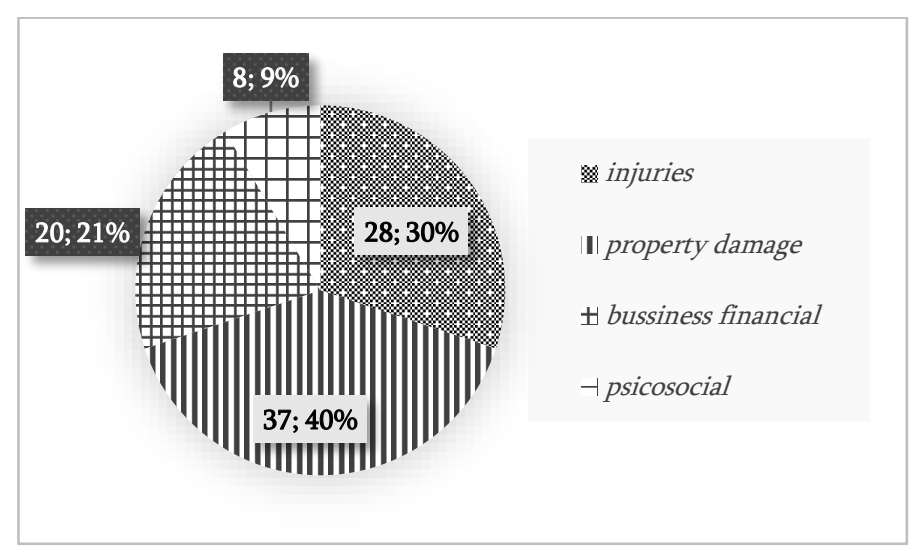

Gambar 2 Konsekuensi bahaya pada kegiatan pengawasan kedatangan kapal penangkap ikan 


\section{Kegiatan Pengawasan Kedatangan Kapal Pengangkut Ikan}

Pengawasan kedatangan kapal pengangkut ikan memiliki sub aktivitas hampir sama dengan pengawasan kedatangan kapal penangkap ikan dengan jumlah sepuluh sub aktivitas, yaitu : (1) Pemeriksaan SLO lama, (2) Pemeriksaan SPB lama, (3) Pemeriksaan SIPI, (4) Pemeriksaan Surat Keterangan Keterangan Aktivasi VMS, (5) Entri data HPK kedatangan, (6) Perjalanan menuju kapal dari pos pelayanan, (7) Pemeriksaan kesesuaian fisik kapal (kesesuaian tanda selar kapal), (8) Pemeriksaan CCTV, (9) Pemeriksaan kesesuaian jenis ikan yang diangkut, (10) Perjalanan dari kapal menuju pos pelayanan. Konsekuensi bahaya yang mungkin terjadi yaitu celana robek dan terjatuh dari tangga, dua konsekuensi bahaya tersebut terjadi pada sub aktivitas perjalanan dari dan menuju objek pengawasan serta aktivitas pemeriksaan CCTV, nilai total delapan konsekuensi dari aktivitas tersebut adalah 10, nilai tersebut masuk kedalam kriteria konsekuensi 4 yaitu severe (parah). Dari keseluruhan aktivitas pada kegiatan pengawasan kedatangan kapal pengangkut ikan berdampak pada konsekuensi injuries, property damage, bussiness financial and psicosocial impact dengan nilai berturut-turut 31 , 38, 21 dan 10. Psicosocial impact masuk dalam dampak potensi bahaya terjatuh dari tangga karena dapat menimbulkan trauma dikemudian hari, dapat dilihat pada gambar 3. Kegiatan tersebut menimbulkan nilai konsekuensi yang besar karena aktivitas dilakukan melewati tangga dengan potensi bahaya terbesar terjatuh dari tangga. Gambar 3 menunjukkan persentase konsekuensi bahaya pada kegiatan pengawasan kedatangan kapal pengangkut ikan.

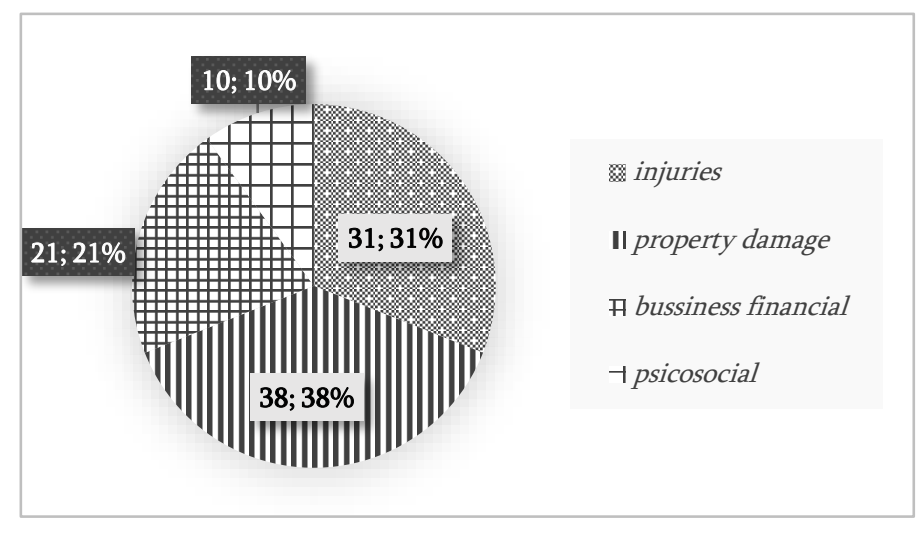

Gambar 3 Konsekuensi bahaya pada kegiatan pengawasan kedatangan kapal pengangkut ikan

\section{Kegiatan Pengawasan Keberangkatan Kapal Penangkap Ikan}

Berbeda dengan pengawasan kedatangan kapal, aktivitas pada kegiatan ini berjumlah dua belas sub aktivitas, yaitu: (1) Pemeriksaan HPK kedatangan, (2) Pemeriksaan SIPI, (3) Pemeriksaan VMS melalui web, (4) Entri data HPK keberangkatan, (5) Entri data SLO, (6) Perjalanan menuju kapal dari pos pelayanan, (7) Pemeriksaan kesesuaian fisik kapal (kesesuaian tanda selar kapal), (8) Pemeriksaan alat tangkap, (9) Pemeriksaan alat bantu penangkapan, (10) Pemeriksaan keaktifan VMS (11) Pemeriksaan kesesuaian nomor mesin, (12) Perjalanan dari kapal menuju pos pelayanan. Jumlah sub aktivitas lebih banyak karena kegiatan ini merupakan salah satu prasyarat untuk terbitnya SLO dengan ketentuan kelaikan kapal perikanan yang diperiksa dituangkan dalam hasil pemeriksaan keberangkatan kapal penangkap ikan sebagai dasar terbitnya SLO. Konsekuensi bahaya terjadi pada aktivitas perjalanan dari dan menuju objek pengawasan serta pemeriksaan Vessel Monitoring System (VMS) berupa jatuh dari tangga dan celana robek. Total delapan konsekuensi pada aktivitas-aktivitas tersebut berjumlah 10, kriteria konsekuensi untuk nilai 10 adalah 4 yaitu severe (parah). Nilai konsekuensi tertingi pada kegiatan ini berdampak kepada injuries, properti damage, environmental damage, bussiness financial dan psicosocial impact dengan jumlah masing-masing 50, 45, 1, 33 dan 12. Nilai persentase konsekuensi bahaya yang terdampak dapat dilihat pada gambar 4. 


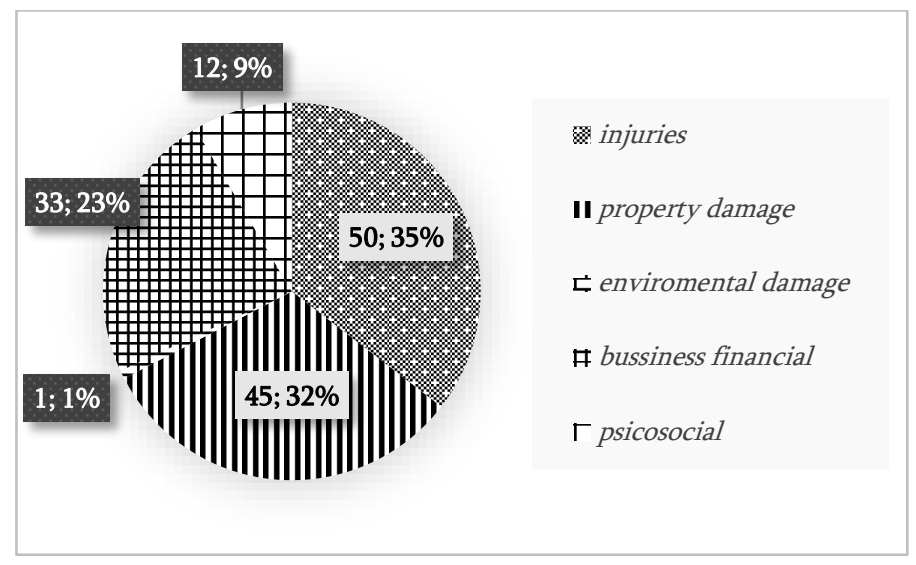

Gambar 4 Konsekuensi bahaya pada kegiatan pengawasan keberangkatan kapal penangkap ikan

\section{Kegiatan Keberangkatan Kapal Pengangkut Ikan}

Kegiatan pengawasan keberangkatan kapal pengangkut ikan pada dasarnya sama dengan pengawasan yang dilakukan pada keberangkatan kapal penangkap ikan, dengan sebelas sub aktivitas yaitu: (1) Pemeriksaan HPK kedatangan, (2) Pemeriksaan SIKPI, (3) Pemeriksaan VMS melalui web, (4) Entri data HPK keberangkatan, (5) Entri data SLO, (6) Perjalanan menuju kapal dari pos pelayanan, (7) Pemeriksaan kesesuaian fisik kapal (kesesuaian tanda selar kapal), (8) Pemeriksaan CCTV, (9) Pemeriksaan keaktifan VMS, (10) Pemeriksaan kesesuaian nomor mesin, (11) Perjalanan dari kapal menuju pos pelayanan. Konsekuensi bahaya yang terjadi lebih banyak walaupun bentuk konsekuensinya sama yaitu terjatuh dari tangga dan celana robek. Aktivitas yang menyebabkan konsekuensi bahaya tersebut adalah perjalanan dari dan menuju objek pengawasan, sub aktivitas pemeriksaan Vessel monitoring System (VMS) dan pemeriksaan CCTV, Nilai total delapan konsekuensi dari sub aktivitas tersebut adalah sama yaitu 10, skala konsekuensi dari nilai 10 masuk kedalam kriteria 4 yaitu severe (parah). Kegiatan pengawasan keberangkatan kapal pengangkut ikan berdampak kepada konsekuensi injuries, properti damage, enviromental damage, bussiness financial dan psicosocial impact, dengan nilai berurutan 47, 46, 1, 31 dan 14. Nilai persentae konsekuensi bahaya pada kegiatan ini disampaikan pada Gambar 5.

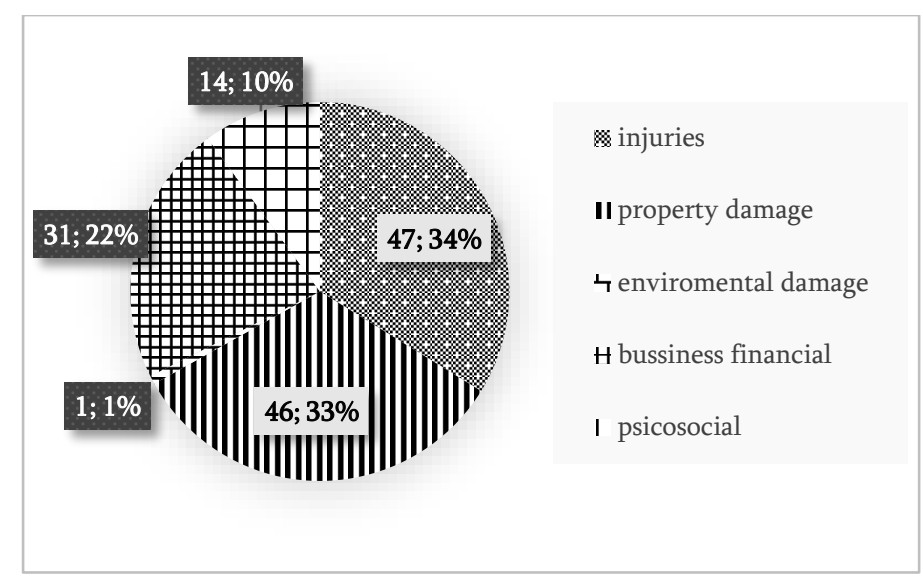

Gambar 5 Konsekuensi bahaya pada kegiatan pengawasan keberangkatan kapal pengangkut ikan

\section{Aktivitas Pasca Pengawasan}

Kegiatan pasca pengawasan memiliki 4 sub aktivitas yaitu : (1) Penyusunan properti pengawasan (2) Perjalanan dari pos pelayanan Muara Baru menuju kantor Pangkalan PSDKP Jakarta, (3) Perjalanan dari pos pelayanan Muara Angke menuju kantor Pangkalan PSDKP Jakarta (4) Presensi kehadiran 
pulang. Pada sub aktivitas perjalanan dari pos pelayanan Muara Angke menuju kantor pangkalan PSDKP Jakarta memberikan nilai konsekuensi terbesar dengan nilai total konsekuensi 12 dari delapan konsekuensi pada aktivitas tersebut, dengan konsekuensi bahayanya adalah kecelakaan. Nilai total 12 menunjukkan kriteria konsekuensi 5 yaitu very severe (sangat parah). Secara keseluruhan aktivitas ini memberikan nilai total konsekuensi terbesar berdampak pada injuries dan properti damage dengan jumlah masing-masing 8 dan 11. Gambar 6 menunjukkan nilai persentase konsekuensi bahaya pada kegiatan pasca-pengawasan.

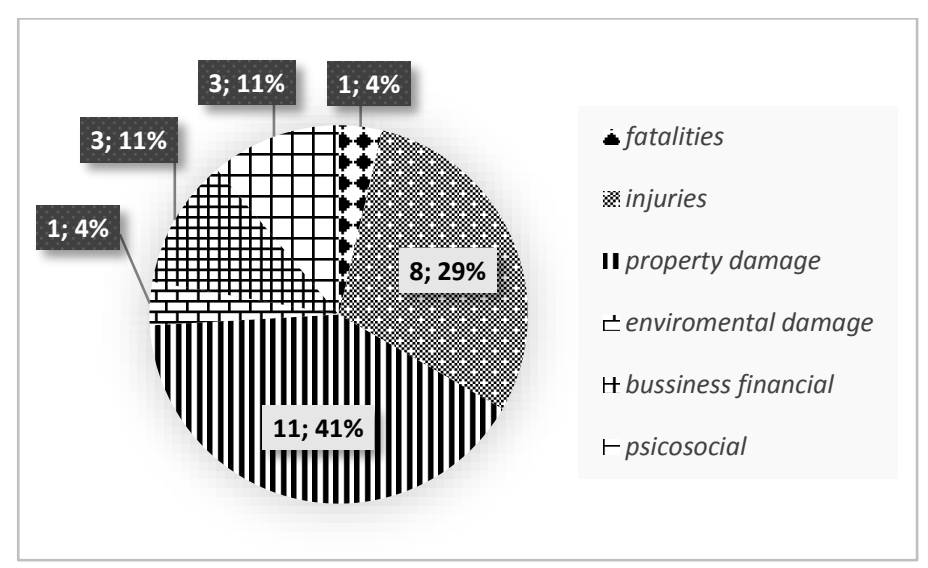

Gambar 6 Konsekuensi bahaya pada kegiatan pasca-pengawasan

\section{KESIMPULAN DAN SARAN}

Aktivitas pengawasan kedatangan dan keberangkatan kapal perikanan mempunyai enam kegiatan utama dengan nilai konsekuensi bahaya terbesar pada kegiatan pra dan pasca pengawasan pada tingkat 5 (very severe). Adapun saran dari penelitian adalah kegiatan pengawasan kedatangan dan keberangkatan kapal perikanan oleh pengawas perikanan harus didukung dengan peralatan keselamatan yang dapat mengurangi konsekuensi bahaya, serta kesiap siagaan dari pengawas perikanan dalam melakukan aktivitas pengawasan kedatangan dan keberangkatan kapal walaupun kegiatan tersebut merupakan kegiatan rutin yang dilakukan setiap hari.

\section{DAFTAR PUSTAKA}

Aji SP, Iskandar BH, Purwangka F. 2017 Identifikasi Bahaya Pada Aktivitas Patroli Laut Oleh Pengawas Perikanan di Jakarta. Jurnal Albacore 1(1) : 047-067.

Ambarani AY dan Tualeka AR. 2016. Hazard Identification And Risk Assessment (HIRA) Pada Proses Fabrikasi Plate Tanki 42-T-501a PT Pertamina (Persero) Ru Vi Balongan. The Indonesian Journal of Occupational Safety and Health. 5 (2): 192-203.

[EMO] Emergency Management Ontario 2012. Hazard Identification and Risk Assessment Workbook.Ontario (CA): 24hlm.

Handayani SN, Wisudo SH, Iskandar BH, Haluan J. 2014. Intensitas kerja aktivitas nelayan pada pengoperasian soma pajeko (mini purse seine) di Bitung. JTPK. 5(1):1-13.

[ILO] International Labour Organization 2013. Keselamatan dan Kesehatan Kerja Sarana untuk Produktivitas. Jakarta (ID). ILO Jakarta

[KKP] Kementerian Kelautan dan Perikanan 2016. Peraturan Menteri Kelautan dan Perikanan nomor 33 tahun 2016 tentang Organisasi dan Tata Kerja Unit Pelaksana Teknis Pengawasan Sumber Daya Kelautan dan Perikanan. Jakarta (ID): KKP. 
[KKP] Kementerian Kelautan dan Perikanan 2017. Peraturan Menteri Kelautan dan Perikanan nomor 1 tahun 2017 tentang Surat Laik Operasi Kapal Perikanan. Jakarta (ID): KKP.

Minggo YD, Iskandar BH, Purwangka F. 2017. Intensitas kerja aktivitas nelayan purse seinedi Kabupaten Sikka. ALBACORE. 1(2):185-197.

Pemerintah Republik Indonesia 2009. Undang-undang Nomor 45 Tahun 2009 tentang Perubahan atas Undang-undang Nomor 31 tahun 2004 tentang Perikanan.Jakarta (ID): Sekreteriat Negara.

Purwangka F. 2013. Keselamatan kerja nelayan pada operasi penangkapan ikan menggunakan payang di Palabuhanratu, Jawa Barat [disertasi]. Bogor (ID): Institut Pertanian Bogor.

Ramli S. 2009. Sistem Manajemen Keselamatan dan Kesehatan Kerja OHSAS 18001. Jakarta (ID): Dian Rakyat. $257 \mathrm{hlm}$.

Retnowati D 2017. Analisa Risiko K3 dengan Pendekatan Hazard and Operability Study (Hazop). Engineering and Sains Journal 1 (1) : 41-46

Sanusi, Despriadi A. Yusdinata Z 2017. Analisa Potensi Bahaya dan Risiko Kegiatan Bongkar Muat di Pelabuhan PT. Sarana Citranusa Kabil Dengan Metode HIRARC. Sekolah Tinggi Teknik Ibnu Sina 2 (1): 119-125.

Susihono W dan Rini FA 2013. Penerapan Sistem Manajemen Keselamatan dan kesehatan Kerja (K3) dan Identifikasi Potensi Bahaya Kerja (Studi kasus di PT. LTX Kota Cilegon- Banten).Jurnal Spektrum Indonesia 2(2) :117-242 